\title{
PENDAMPINGAN DAN SOSIALISASI DESAIN PEMANFAATAN KOLAM RETENSI SEBAGAI PENCEGAHAN BANJIR BERNILAI EKONOMIS
}

\author{
Lilik Ariyanto*1, Dede Mulyana ${ }^{2}$ \\ ${ }^{1,2}$ Universitas Sang Bumi Ruwa Jurai \\ e-mail: *1 lilikariyanto2020@gmail.com,*2mulyana22071990@gmail.com
}

\begin{abstract}
Abstrak
Tujuan kegiatan pengabdian ini adalah melaksanakan pendampingan dan sosialisasi tentang pembuatan kolam retensi bernilai ekonomis di Pekon Seray Kabupaten Pesisir Barat. Metode yang digunakan adalah sosialisai dan pendampingan dalam lokakarya sehari terhadap 30 partisipan. Hasil pengabdian ini dapat diperoleh kesimpulan bahwa Pendampingan dan Sosialisasi Desain Pemanfaatan Kolam Retensi Sebagai Pencegahan Banjir Bernilai Ekonomis dapat terlaksana dengan baik sesuai dengan waktu yang telah dijadwalkan. Peserta mulai memahami dan menyadari bahwa pencegahan banjir dapat dimulai dan diawali dari rumah dengan pemanfaatan lahan di sekitar rumah untuk dibuat kolam retensi sekaligus dapat dimanfaatkan untuk budidaya ikan air tawar. hampir seluruhnya langsung melakukan inventarisasi lahan di sekitar rumah tinggal untuk didesain tata letak dan besaran kolam retensi yang akan dibuat. Bahkan sebagian peserta, sekitar 10 orang (30\%) langsung secara detail Menyusun rencana kebutuhan biaya untuk pembuatan kolam retensi di sekitar tempat tinggalnya dan berkoordinasi dengan pihak pekon untuk bantuan Pendanaan.
\end{abstract}

Kata kunci : Desain Kolam, Kolam Retensi, Pencegahan Banjir

\begin{abstract}
The purpose of this service activity is to carry out mentoring and socialization about the creation of an economical value retention pond in Pekon Seray, Pesisir Barat Regency. The method used is socialization and mentoring in a one day workshop for 30 participants. The results of this service can be concluded that the Assistance and Socialization of the Design of Utilization of Retention Ponds as Economic Value Flood Prevention can be carried out properly according to the scheduled time. Participants began to understand and realize that flood prevention can be started and started from the house by using the land around the house to make a retention pond which can also be used for freshwater fish farming. almost all of them directly carry out an inventory of the land around the house to design the layout and size of the retention pond to be made. Even some of the participants, around 10 (30\%) directly in detail drew up a budget plan for the construction of a retention pond around their residence and coordinated with the village community for funding assistance.
\end{abstract}

Keywords : Pond Design, Retention Pond, Flood Prevention

\section{PENDAHULUAN}

Perkembangan sebuah wilayah yang berada di daerah pesisir selalu dipengaruhi oleh kondisi alam [1] dan iklim [2] yang terkadang di luar batas kemampuan masyarakat di sekitarnya dalam memperkirakan siklusnya. Seiring sejalan dengan perubahan tata guna lahan di sebuah wilayah karena semakin berkembangnya jumlah penduduk yang secara linier dibarengi dengan peningkatan kebutuhan akan tempat tinggal, maka 
akan berdampak pada kondisi dan situasi lingkungannya [3].

Pekon Seray merupakan salah satu wilayah di Kabupaten Pesisir Barat Provinsi Lampung yang berada di wilayah pesisir pantai dengan pengaruh kondisi dan fenomena alam pesisir yang seringkali berdampak pada kehidupan masyarakat di sekitarnya. Pertumbuhan penduduk di wilayah Kabupaten Pesisir Barat pada beberapatahun terakhir berada di angka $0.82 \%$ dengan kepadatan penduduk 65 jiwa per $\mathrm{km} 2$ berdasarkan data BPS Tahun 2019.

Keberadaannya di sekitar pesisir pantai juga merupakan sebuah potensi pariwisata yang potensial dan menarik untuk terus dikembangkan [4] oleh Pemerintah Daerah setempat. Saat ini mulai dibangun lokasi wisata di sekitarnya diantaranya adalah Labuhan Jukung dengan konsep penataan terpadu dengan kompleks perkantoran, pusat ekonomi dan bisnis [5].

Seiring dengan semakin meningkatnya perkembangan daerah wisata maka akan semakin meningkatkan kunjungan wisatawan khususnya wisatawan mancanegara [6] ke lokasi di sekitar Pekon Seray, hal ini akan berpengaruh pada semakin padatnya kebutuhan akan rumah tinggal maupun pembangunan hotel dan penginapan bagi wisatawan yang akan berkunjung [7].

Pembangunan kawasan permukiman dan wisata yang terus menerus tanpa perencanaan jangka panjang yang memadai akan berdampak pada penurunan kondisi lingkungan dengan terjadinya degradasi daerah aliran sungai [8] yang bermuara di sekitar pesisir pantai Pekon Seray. Pada saat musim penghujan maupun saat air pasang dari pantai akan terhambat mengalir di sungai-sungai yang ada karena telah terjadi penurunan fungsi sungai dan saluran drainase lainnya sehingga berpotensi terjadinya banjir berulang dan terus-menerus terjadi setiap tahunnya [9]. Kondisi tersebut perlu perhatian dari semua pihak yang terlibat agar di masa yang akan datang tidak berdampak kerugian material maupun korban jiwa di masyarakat. Diperlukan pemikiran dan perencanaan pencegahan dan pengendalian banjir yang dapat dilaksanakan secara bertahap dan dengan melibatkan partisipasi aktif masyarakat [10].

Beberapa permasalahan yang ditemukan di sekitar wilyah Pekon Seray adalah kejadian banjir setiap musim hujan dan masih tersedianya banyak lahan kosong di sekitar rumah warga yang belum dimanfaatkan sehingga upaya pencegahan dan pengendalian banjir dengan sistem kolam retensi sekaligus untuk dimanfaatkan untuk budidaya ikan air tawar dirasa cukup tepat untuk diterapkan, selain manfaat pengendalian banjir dengan menampung aliran banjir ke kolam retensi juga dapat menambah penghasilan keluarga dengan budidaya ikan air tawar seperti ikan lele, gurami, nila dan lainnya. Dengan peningkatan aliran tersebut perlu dikaji lebih mendalam terkait besaran curah hujan yang turun pada DAS Way Pisang. antarbaris diberi spasi tunggal. 


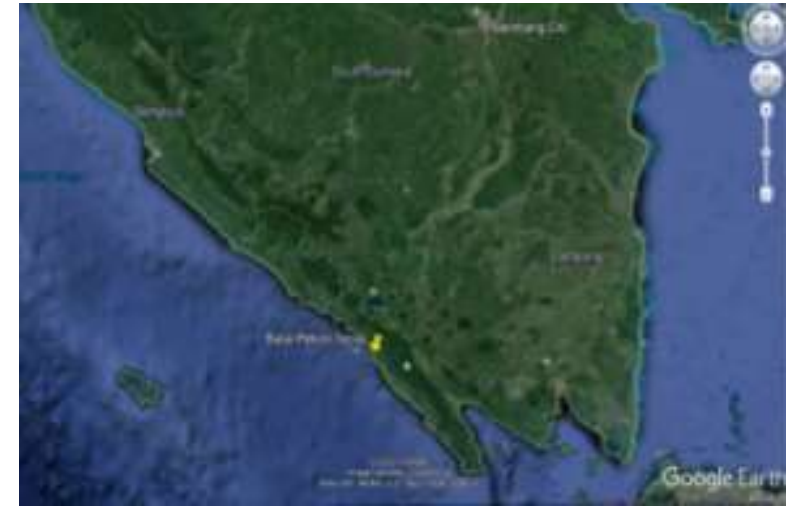

Gambar 1. Peta Lokasi Pekon Seray Kabupaten

Pesisir Barat

Berdasarkan permasalahan yang teridentifikasi di lokasi sekitar Pekon Seray dan kondisi serta latar belakang sosial kemasyarakatannya, maka solusi yang ditawarkan dalam rangka kegiatan PKM ini adalah melaksanakan pendampingan dan sosialisasi tentang pembuatan kolam retensi bernilai ekonomis, dimana secara teknis kolamkolam retensi yang dibangun di sekitar rumah tinggal warga Pekon Seray akan dapat mengurangi aliran debit banjir di permukaan saat terjadi hujan di sepanjang musim penghujan. Selain itu kolam-kolam retensi tersebut dapat dimanfaatkan secara ekonomis untuk budidaya ikan air tawar yang dapat menjadi solusi dalam memenuhi kebutuhan protein keluarga khususnya di masa pandemi serta dalam jumlah yang besar dapat dijual ke pasar terdekat untuk memperoleh penghasilan tambahan yang dapat meningkatkan kesejahteraan masyarakat.

\section{METODE}

Dalam pelaksanaan kegiatan pengabdian pada masyarakat ini, metode yang digunakan adalah pendampingan dalam lokakarya sehari, yang dihadiri oleh tokoh masyarakat dan perwakilan warga masyarakat sebanyak 30 orang bertempat di Balai Pekon mulai jam 8.00 - 16.00 WIB dengan rincian kegiatan lokakarya berupa :

1. Sosialisasi pentingnya pencegahan banjir di lingkungan sekitar tempat tinggal

2. Sosialisasi alternatif cara-cara pencegahan dampak banjir

3. Sosialisasi beberapa desain infrastruktur pencegahan banjir

4. Sosialisasi perhitungan nilai manfaar dan nilai ekonomis dari desain kolam retensi pencegah banjir

Setelah selesai kegiatan lokakarya dan sosialisasi maka dilanjutkan dengan peninjauan lokasi di sekitar tempat tinggal warga pekon yang berpotensi untuk dibuat sebagai kolam retensi pencegahan banjir sekaligus bernilai ekonomis untuk budidaya ikan air tawar.

\section{HASIL DAN PEMBAHASAN}

Berdasarkan hasil survey dan pengamatan di lokasi, keberadaan kolam retensi banjir bisa dibangun di sisi kanan, kiri 
dan belakang rumah penduduk yang masih tersedia lahan kosong.

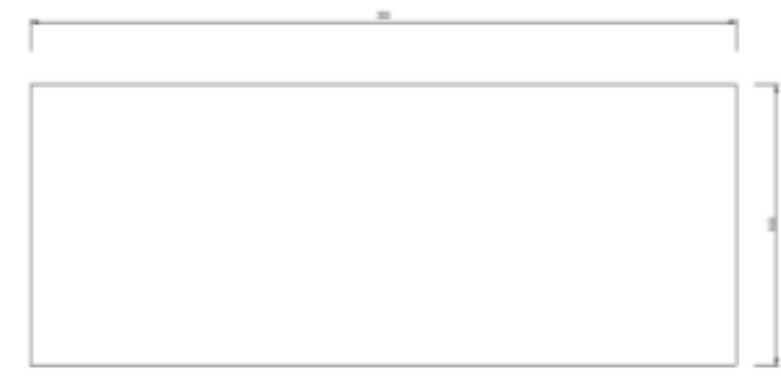

Gambar 2. Kolam Retensi (Tampak Atas)

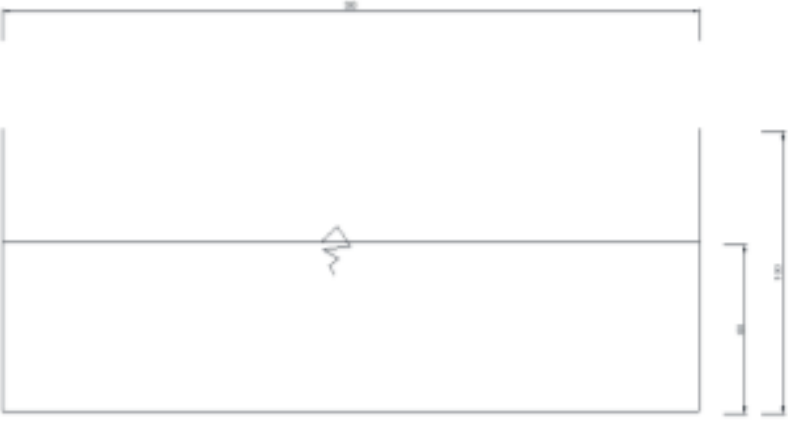

Gambar 3. Kolam Retensi Tampak Samping

Keberadaan kolam retensi banjir di lokasi rencana PKM selain berfungsi untuk mengurangi besaran aliran banjir ke sungai pada saat hujan juga dapat dimanfaatkan untuk memelihara ikan air tawar pada saat tidak terjadi hujan.

Beberapa jenis ikan air tawar yang mampu bertahan hidup di kolam retensi diantaranya lele, gurami, nila dan lainnya. Dengan memanfaatkan kolam retensi banjir untuk memelihara ikan, maka dapat mendatangkan keuntungan ekonomis bagi keluarga setidaknya dapat memenuhi kebutuhan protein untuk keluarga. Dalam jumlah besar hasil budidaya ikan air tawar dapat dijual ke Pasar di sekitar permukiman warga masyarakat.

\subsection{Rencana Anggaran Biaya Kolam Retensi Dengan memperhatikan kondisi lokasi} PKM dan konsep desain kolam retensi banjir bernilai ekonomis untuk budidaya ikan air tawar, maka dapat diketahui bahwa untuk dapat melaksanakan pembuatan kolam retensi tersebut Diperlukan biaya sebagai berikut.

Tabel 1. Rencana Anggaran Biaya Kolam Retensi Bernilai Ekonomis

\begin{tabular}{|c|c|c|c|c|c|c|}
\hline No & Kegiatan & Satuan & Jumlah & Harga Satuan & & Biaya \\
\hline 1 & 2 & 3 & 4 & 5 & & $6=4 \times 5$ \\
\hline \multicolumn{7}{|c|}{\begin{tabular}{|l|l|} 
& Kolam Retensi \\
\end{tabular}} \\
\hline & Galian dan Pendalaman Kolam & $\mathrm{m} 3$ & $50 \mathrm{~h}$ & $66,574.75$ & Rp & $3,328,737,50$ \\
\hline & Pasangan Bata & $\mathrm{m} 2$ & $50 \mathrm{~h}$ & $187,220.00$ & Rp & $9,361,000,00$ \\
\hline & Plester dan Acian & $\mathrm{m} 2$ & & $129,503.00$ & Rp & $6,475,150,00$ \\
\hline & Bibiti ikan ukuran $46 / 57-1000$ ekor $/ \mathrm{m}^{3}$ & ekor & $50000 \mathrm{~A}$ & 200.00 & Rp & $10,000,000.00$ \\
\hline & Pipa Instalasi dia 4 inch & batang & $20 \mathrm{~h}$ & $475,000,00$ & Rp & $9,500,000,00$ \\
\hline & Pakan ikan perbandingan $1.5 \mathrm{~kg}$ per hari per 1000 bibit & $\mathrm{kg}$ & $50000 \mathrm{~h}$ & $10,000,00$ & Rp & $750,000,00$ \\
\hline & Bibit sayuran hidroponik & bungkus & $100 \mathrm{~h}$ & $15,000,00$ & Rp & $1,500,000.00$ \\
\hline \multirow{2}{*}{\multicolumn{2}{|c|}{8 Pupuk dari kotoran hewan }} & $2 a k$ & $50 \mathrm{~h}$ & $20,000,00$ & Rp & $1,000,000,00$ \\
\hline & & & & Total & Rp & $41,914,887,50$ \\
\hline
\end{tabular}

\subsection{Evaluasi Kegiatan}

Secara keseluruhan kegiatan Pendampingan dan Sosialisasi Desain Pemanfaatan Kolam Retensi Sebagai Pencegahan Banjir Bernilai Ekonomis dapat terlaksana dengan baik sesuai dengan waktu yang telah dijadwalkan serta melihat antusiasme warga masyarakat sebagai peserta mulai memahami dan menyadari bahwa pencegahan banjir dapat dimulai dan diawali dari rumah dengan pemanfaatan lahan di sekitar rumah untuk dibuat kolam retensi sekaligus dapat 
dimanfaatkan untuk budidaya ikan air tawar sehingga dapat memenuhi kebutuhan protein skala rumah tangga. Selain itu dalam skala yang lebih besar dapat dijual dan menambah penghasilan keluarga. Dari sekitar 30 peserta kegiatan, hampir seluruhnya langsung melakukan inventarisasi lahan di sekitar rumah tinggal untuk didesain tata letak dan besaran kolam retensi yang akan dibuat. Bahkan sebagian peserta, sekitar 10 orang (30\%) langsung secara detail Menyusun rencana kebutuhan biaya untuk pembuatan kolam retensi di sekitar tempat tinggalnya dan berkoordinasi dengan pihak pekon untuk bantuan Pendanaan.

\section{SIMPULAN}

Berdasarkan hasil kegiatan dan analisis serta perhitungan yang telah dilakukan dalam pengabdian ini, dapat diperoleh beberapa kesimpulan sebagai berikut:

1. Peserta mulai memahami dan menyadari bahwa pencegahan banjir dapat dimulai dan diawali dari rumah dengan pemanfaatan lahan di sekitar rumah untuk dibuat kolam retensi sekaligus dapat dimanfaatkan untuk budidaya ikan air tawar.

2. Hampir seluruhnya langsung melakukan inventarisasi lahan di sekitar rumah tinggal untuk didesain tata letak dan besaran kolam retensi yang akan dibuat. Bahkan sebagian peserta, sekitar 10 orang (30\%) langsung secara detail Menyusun rencana kebutuhan biaya untuk pembuatan kolam retensi di sekitar tempat tinggalnya dan berkoordinasi dengan pihak pekon untuk bantuan Pendanaan.

3. Terbangunnya semangat untuk lebih peduli terhadap kondisi lingkungan terutama dalam hal mensikapi kejadian banjir dan kekurangan air dengan pendekatan sistem teknologi tepat guna berupa kolam retensi bernilai ekonomis setelah mengikuti kegiatan PKM.

\section{SARAN}

Berdasarkan hasil pengabdian ini sebagaimana telah disimpulkan di atas, Penulis dapat menyusun beberapa saran dan rekomendasi kepada instansi terkait, diantaranya adalah sebagai berikut:

1. Perlunya kegiatan pendampingan sejenis secara rutin dari sivitas akademika kepada masyarakat terkait pemahaman dan peningkatan kesadaran dan kepedulian terhadap kondisi lingkungan di sekitarnya

2. Diperlukan sinergisitas antara Pemerintah Daerah dan semua 
elemen masyarakat untuk secara rutin melakukan pendampingan kepada masyarakat di wilayahnya terkait peningkatan pemahaman dan kesadaran dalam menjaga lingkungan;

3. Diperlukan alokasi program khusus untuk pendampingan sebagai bagian dari pengabdian kepada masyarakat (PKM) oleh Universitas Sang Bumi Ruwa Jurai sebagai implementasi Tri Dharma Perguruan Tinggi.

\section{UCAPAN TERIMA KASIH}

Penulis mengucapkan terima kasih kepada Universitas Sang Bumi Ruwa Jurai baik Pimpinan Universitas, Unit Fakultas dan Rekan Dosen serta Mahasiswa yang bersedia berkolaborasi dalam kegiatan pengabdian ini. Terimakasih juga kepada tokoh masyarakat dan Kepala Pekon Seray Kecamatan Pesisir Tengah Kabupaten Pesisir Barat serta pihak-pihak yang telah memberi dukungan moral dan material terhadap program pengabdian masyarakat ini.

\section{DAFTAR PUSTAKA}

[1] E. Salim, "Legislasi dan Perubahan Iklim," $J$. Legis. Indones., vol. 6, no. 1, pp. 1-14, 2018, [Online]. Available: http://ejurnal.peraturan.go.id/index.php/jli/article/do wnload/308/193.

[2] A. Rosihan, W. Widyawati, and A. H. Hidayat, "Preferensi resiko petani dalam alokasi input usaha tani jagung menggunakan Model Just And Pope," J. Ekon. Pertan. dan Agribisnis, vol. 3, no. 2, pp. 449-459, 2019.

[3] H. Afriansyah, "Administrasi hubungan sekolah dengan masyarakat," 2019.

[4] S. Prastiwi and Meirinawati, "Manajemen Strategi Dinas Kebudayaan Dan Pariwisata Kabupaten Bojonegoro Dalm Mengembangkan Potensi Objek Wisata Edukasi Little Teksas Wonocolo," Publika, vol. 4, no. 11, 2016.

[5] M. N. Sari, F. Yuliasara, and M. Mahmiah, "Dampak Virus Corona (Covid-19) Terhadap Sektor Kelautan dan Perikanan: A Literature Review," J. Ris. Kelaut. Trop. (Journal Trop. Mar. Res., vol. 2, no. 2, pp. 59-66, 2020, doi: 10.30649/jrkt.v2i2.41.

[6] S. Intyaswono, E. Yulianto, and M. K. Mawardi, "Peran Strategi City Branding Kota Batu dalam Trend Peningkatan Kunjungan Wisatawan Mancanegara," J. Adm. Bisnis, vol. 30, no. 1, pp. 65-73, 2016, [Online]. Available:

administrasibisnis.studentjournal.ub.ac.id\%0 A.

[7] F. Sari and E. Pangestuti, "Pengaruh Electronic Word of Mouth (E-Wom) Terhadap Minat Berkunjung dan Keputusan Berkunjung (Studi pada Wisata Coban Rais BKPH Pujon)," J. Adm. Bisnis, vol. 54, no. 1, pp. 189-196, 2018, [Online]. Available: http://administrasibisnis.studentjournal.ub.ac. 
id/index.php/jab/article/view/2231.

[8] J. Heyde, M. C. Lukas, and M. Flitner, "Pembayaran Jasa Lingkungan: Instrumen baru untuk mengatasi masalah lingkungan berkepanjangan di daerah aliran sungai dan pesisir di Indonesia ?," Univ. Bremen, vol. Artec-pape, no. 214, 2017.

[9] I. G. N. Santika, "Strategi Meningkatkan Kualitas SDM Masyarakat Desa Padangsambian Kaja Melalui Pendidikan Karakter Berbasiskan Kepedulian Lingkungan Untuk Membebaskannya Dari Bencana Banjir," Widya Accarya, vol. 9, no. $1,2018$.

[10] S. R. Nurbaiti and A. N. Bambang, "Faktor Faktor yang Mempengaruhi Partisipasi Masyarakat dalam Pelaksanaan Program Corporate Social Responsibility ( CSR ) Factors Affecting Community Participation in the Implementation of Corporate Social Responsibility Program," Proceeding Biol. Educ. Conf., vol. 14, no. 1, pp. 224-228, 2017. 